\title{
Imperial Debris: Reflections on the Lisbon Cityscape in Contemporary Portuguese Fiction
} PATRÍCIA MARTINHO FERREIRA

University of Massachusetts, Amherst

\begin{abstract}
This essay focuses on the literary image of contemporary Lisbon. Through an analysis of the anthology Lisbon Tales and Trails (2017) and Djaimilia Pereira de Almeida's Luanda, Lisboa, Paraíso (2018), I examine how Lisbon's representation on a global stage exposes the complexities and ambiguities of a metropolitan area deeply connected to the legacies of empire. Moving through fictional texts from the city center to the suburban periphery, I offer a focused reflection on Lisbon's postcolonial/post-imperial ethnoscape.
\end{abstract}

Keywords: Portugal, postcolonial, African Lisbon, Afro-Portuguese, Afropean

“The city must never be confused,” states Marco Polo in Italo Calvino's Invisible Cities, "with the words that describe it" (61). He goes on to add that there is nonetheless a connection between the two. It is useful to have these points in mind when contemplating the ways in which contemporary fiction writers portray Lisbon, especially when one considers what these writers choose to discuss and what they leave out. In the context of today's symbolic economy, in which cities compete for visibility in the market of global culture, Lisbon has asserted itself as a city capable of offering unique living and touristic experiences. Tourism websites commonly inform readers that Portugal and its capital are now among the world's top tourist destinations, a fact widely promoted by Portuguese private travel agencies as well as by public and government institutions. 
The book Lisbon Tales and Trails, a collection of work by twenty writers and twenty illustrators first published in Portuguese in 2016 under the title, Guia ver e ler Lisboa, is marketed as a pocket guide and promoted by the Lisbon city council as a way to approach Lisbon through an artistic lens. Upon examining the short stories, one notes that the writers included in the anthology share (to quote the book's synopsis) their "secret, nostalgic, imaginary, historical, lost, underground, dirty or utopian” Lisbon. That is, rather than an unvarying representation of the capital, the reader encounters a distinct and unique Lisbon in each of the texts. The collection unveils Portuguese history and culture by mapping places, objects, figures, and events. The country's present and past (both distant and more recent) are intertwined in such a way as to offer a general portrait of Lisbon as one of the oldest cities in Western Europe and one that has been shaped by various peoples over many centuries. Regarding the current touristic boom, one common thread in Lisbon Tales and Trails has to do, surprisingly, with its negative effects. For instance, the narrators of Joana Bértholo’s “Memory Street View” and Patrícia Portela’s “Subterranean Lisbon” share a sense of loss and nostalgia related to the "renovation fever" that has profoundly altered their city.

While Lisbon Tales and Trails does not claim to be a comprehensive collection of all of the ways the city can be perceived, there are nonetheless significant features of the Lisbon ethnoscape that remain invisible or insufficiently represented in this collection of short stories-features that are necessary to consider if one wishes to have an adequate understanding of the city's social dynamics as a whole. In speaking of Lisbon's ethnoscape, I am adapting Arjun Appadurai's concept, which he defines as: "the landscape of persons who constitute the shifting world in which we live: tourists, immigrants, refugees, exiles, guest workers, and other moving groups and individuals constitute an essential feature of the world and appear to affect the politics of (and between) nations to a hitherto unprecedented degree” (192).With this in mind, one begins to see the stark representational lacunae in Lisbon Tales and Trails, especially with respect to two of Appadurai's "moving groups."

In the first place, there are the tens of thousands of commuters who pour into the Lisbon city center every day to work. In fact, even as Lisbon Tales and Trails encourages the reader to walk the most unexpected paths in Lisbon, the contributors consistently neglect the outskirts of the Portuguese capital, which 
are an essential part of the city's life. One gets only a glimpse of this reality in the opening short story, "Ulyssea," which seems to function as a prologue, given that it is curiously attributed to an anonymous author. From the perspective of the narrative's frustrated lovers, who cross the Tagus River every day to reach the center of the city "with a broken back, aching arms and bloodshot eyes" (17), Lisbon is "the sewer we sink into every day" (17). This text's disenchanted tone is amplified by the impossibility of fulfilling a romantic relationship, as if the lovers were trapped in their monotonous and unsurprising life.

It is also striking that most of the writers in Lisbon Tales and Trails largely ignore migrant experiences, specifically those of Lusophone African origin and their descendants. The last two decades have seen the rise of "African Lisbon"as a point of departure for a transnational cultural movement bringing together cultural expressions from the broader Portuguese-speaking world-and the documentary Lusofonia, a (r)evolução (2006) and projects such as Conexão Lusófona exemplify the trend of affirming that Lisbon is a hub for a supposed "Lusophone identity." The absence of any mention of this in Lisbon Tales and Trails is all the more puzzling given that the anthology was designed to serve as a touristic guide.

It is worth mentioning briefly here that examples of the inscription of Lisbon's postcolonial ethnoscape abound in the contemporary music scene. The song “Nova Lisboa,” recently released by Dino D’Santiago, a Portuguese singer of Cape Verdean descent, is just one case in point. What is remarkable in this song is its allusion to the role that Lusophone African cultural expressions have played in Lisbon's touristic success. D'Santiago uses both Portuguese and Creole in the song, and he works to reclaim his space in the city by rejecting any involvement in the "selling off" of Lisbon's Afro-descendant communities and their cultural expressions to the many tourists who come to the city each year. Voicing criticism without openly condemning the tourist industry, D’Santiago invites listeners to embrace Lisbon's cultural diversity. The repeated question, “Qualé ideia?” seems to be an invitation to (re)think the implications of being trendy, as well as the possibility of fully "feeling" this new Lisbon without holding back. What this song — and the video clip—also do is put the Black body at the center of the city, while also presenting images of the city center and peripheral neighborhoods mainly associated with the Afro-Portuguese community. Through an original synthesis created by dance, images of colorful 
street art, and scenes from Lisbon's suburbs, the center and the periphery in "Nova Lisboa” become a single space, and barriers dissolve.

Postcolonial literary theorists have consistently asserted that texts reflect, reinforce, and/or work to revise social belief systems. In light of this, I approach Lisbon Tales and Trails asking whether any of its texts provide an account of the diverse experiences of the highly visible African or Afro-Portuguese presence in Lisbon. If any do, how do the narrators and/or other characters perceive and experience the city? With one exception (which I will discuss further on), Lisbon Tales and Trails leaves out the postimperial reality that so pervades contemporary Portuguese society and, more specifically, Lisbon's urban landscape. This reality is, according to many critics and activists, a key element for understanding the social and power dynamics that obtain in the former metropolis of a centuries-long empire. In other words, Lisbon Tales and Trails largely ignores the present-day racialization of Lisbon's urban and suburban realities, as well as its corresponding "situations of economic and socio-spatial vulnerability” (Malheiros and Vala 1084). To be fair, one finds in the short story by Miguel Real about Padre Vieira and in another by Rui Cardoso Pires about Fernão de Magalhães interesting examples of a critical and ironic view of the Portuguese imperial past. Nevertheless, the absence of the Lusophone African diaspora (and of migrant communities in general) in this anthology serves to show the extent to which these groups have been pushed to the "margins" of the capital. Read as a whole, Lisbon Tales and Trails offers an image of Lisbon somehow floating above the complexities of a city intrinsically connected to Portuguese imperial history. This fact is all the more puzzling given that contemporary Portuguese artists have long focused on this connection, and researchers in the humanities and social sciences have likewise examined it at length (Arenas; Peralta and Domingos, among others).

\section{A Hidden Exception}

Apart from the short stories about Vieira and Magalhães, and from scattered references to the colonial war and the repressive nature of the Salazarist regime, only Kalaf Epalanga's text establishes in Lisbon Tales and Trails an explicit connection between Portugal's African colonial past and its current cultural and racial diversity. In “From Avenida Almirante Reis to Areeiro,” Epalanga points 
out the architectural similarities between Lisbon and Benguela, and his narrator explicitly works to make Portuguese imperial history visible in Lisbon's cityscape. When summarizing the exceptionality of the neighborhood of Arroios, Epalanga's narrator states: "in no other neighborhood in the center of the city is it possible to savor a cultural miscegenation as old as the idea of Portugal itself" (103). This may seem at first to convey a celebratory and uncritical view of the present-day ethnic and cultural diversity of Lisbon; such views were common under the Salazarist regime, and they worked mostly to justify the existence of the empire. There is an unresolved tension running through Epalanga's text, however, and it only becomes more acute as the narrator roams the city.

The tension one discerns in Epalanga's "From Avenida Almirante Reis to Areeiro" is intimately connected to the loss of Portugal's African possessions and the sentiments this loss generated. In this sense, the "party" that ended and has left behind a generalized "sadness" might well be a suggestive metaphor for the loss of Portugal's African empire in the 1970s:

The avenue did not seem particularly striking at first, but when I reached the blocks just after the roundabout, a melancholic sight leaped out at me. There was a sadness in the air, in "the party's over” look on people's faces, in the drawn blinds on buildings, which were imposing and beautiful in a way that was very familiar to me. In a not-so-distant past, this place had perhaps represented the future, a certain glamour and exuberance that spread throughout 1920s Europe on the back of faith in social and technological progress. (100-01)

The feeling of melancholy described by the narrator when confronted with the collective "sadness in the air" is reinforced later by the "sudden attack of nostalgia" (101) he has when observing the revivalist atmosphere at "Café Império" that, except for minor details, resembles "another time” (101). It is worth emphasizing here that the narrator's nostalgia seems to be pointing to the sort of imperial debris described by Ann Laura Stoler that one still finds throughout Lisbon's “coffee houses, restaurants, and pastry shops that keep imperial names, decorations, and memories” (Coelho 183). In this regard, the sense of loss and sadness described by Epalanga's narrator is intimately related 
to a certain postimperial topography, to "streets, architecture, and monuments that were either purposely crafted to engage in the colonial venture or to celebrate it” (Coelho 190). At this point in the story, Epalanga's narrator calls attention to the various migrant languages and cultures found in this part of the city: "The avenue revealed new worlds to me. From one block to the next, my ears detected Cantonese, Hindi and a couple of Slavic languages, which, when stripped of all sense of tourist curiosity, make Almirante Reis the most cosmopolitan artery of the city” (101).

Epalanga juxtaposes feelings of familiarity and strangeness ("I felt at home and a stranger at the same time” (102)) as his narrator walks along, alluding to the indifference of the locals, recounting an episode of verbal violence against an immigrant, and personifying the vegetation, specifically the avenue's trees, which suffer due to a scarcity of unpaved ground and an excess of air pollution. The narrator's overall disapproval of "the violent transformations inflicted on the city” (102) reinforces the tension that permeates the entire text. This tension is temporarily broken only when the narrator envisions his Angolan grandfather chuckling when imagining Admiral Reis's amazement at the variety of nationalities represented by the residents of the avenue named after him. With this bit of irony, the narrator deconstructs the colonial myth regarding "the worlds that Portugal gave to the world.” After all, as Lisbon's multicultural diversity finally becomes visible in the former imperial "center," it is undeniably the world that gives worlds to Portugal and not the other way around. This fact is embedded in the narrator's question: "How many Portugals fit inside Arroios?” (102). At the end of the narrative, any account of cultural homogeneity seems an illusion. One can claim that the celebration of Lisbon's multiculturalism in "From Avenida Almirante Reis to Areeiro" does not hide social tensions, which are endemic to a society that for centuries has defined itself in relation to its empire and still looks to understand its postcolonial reality.

\section{Under the Light of Lisbon}

If Lisbon Tales and Trails-perhaps due to the goal and intended audience of the project-does not sufficiently address Lisbon's postcolonial ethnoscape (and particularly the African diaspora), one cannot say the same of Angolan-born Portuguese writer Djaimilia Pereira de Almeida’s 2018 novel, Luanda, Lisboa, 
Paraíso. ${ }^{1}$ By paying close attention to the Lusophone African diaspora living in Portugal and proposing a spatial shift from the center to the outskirts of the city, this novel exposes the complex colonial legacy—a perspective that is left almost untouched by Lisbon Tales and Trails.

Almeida's novel is one of the few fictional works in Portuguese that directly addresses the reality of cooperation between the former metropolis and Portugal's former colonies. Along with the political instability caused by the African civil wars and the socioeconomic crises that followed Portugal's withdrawal from Africa, several governmental agreements related to public education and health are a common reason many Lusophone Africans seek refuge in the former metropolis. By following the journey of a father and son from Luanda to Lisbon (where the latter will have greater access to medical treatment), Almeida reveals the challenges of dealing with illness, social exclusion, poverty, and complex processes of identity construction.

Although organized in three spaces_-Luanda (the point of departure), Lisbon (the point of arrival), and Paraíso (the point of involuntary settlement)—Lisbon

\footnotetext{
${ }^{1}$ The complexities of the African presence in contemporary Portuguese society have been the subject of other novels. One example is Luena, Luanda, Lisboa, the first fictional work by Branca Clara das Neves (2014). In this book, the title of which is curiously echoed in Almeida's novel, the narrator reveals a physical and emotional exile experienced by characters living in the center of Lisbon after they have escaped the Angolan civil war. In both Neves's and Almeida's novels, there is a dominant sense of disillusion. At the beginning of Neves' text, the narrator comments on the protagonist's dispassion regarding the city center through which she walks: "Há muito que passou o tempo da Lisboa fascinante importada dos imaginários que lhe traziam o outro lado do império, quando em Luanda escutava atenta o que contavam e sentia uma atmosfera nova a chegar. [...] Que essa Lisboa devia ser maravilhosa, isso devia, só as histórias! [...] Mas não conseguiu adiantar ver o que viria aí. De repente entrou-lhe pela vida dentro essa cidade aí onde agora tem os pés, e lá foi Maria Benta de espanto em espanto, pendurada no medo e nas decisões dos outros. Desaguou na Lisboa círculo de sobrevivência. [...] Bem outra esta Lisboa” (11-12). Another example worth mentioning is Debaixo da nossa pele: uma viagem by Joaquim Arena (2017). In this memoir-like book, the Lisbon of the narrator's childhood (he is the son of Cape Verdean immigrants) is a place of solitude and anguish. After 40 years, the narrator re-encounters this feeling while visiting the city: “A angústia de então, opressiva e precoce na sua essência, não era mais do que um reflexo da tristeza que existia à minha volta. Estranhamente, reencontro-a nas janelas de guilhotina da antiga fábrica de vidros, nos tufos das plantas nos beirais dos prédios. A solidão quase humana das fachadas dos prédios ou o arrulhar dos pombos no telhado atormentando essa criança insegura que eu era. [...] tudo compondo um quadro esmagadoramente baço e melancólico. [...] Uma lista que poderia continuar por aí fora, de uma forma inquietante” (64-65).
} 
is nonetheless the key space of this narrative; it is the center from which the narrative radiates. As a matter of fact, while the pair are still in Luanda, Lisbon occupies a key role, not only through the imagination of the young boy-who vaguely draws and redraws Lisbon-but also through the enormous expectations of his father, who envisions in this trip the cure for his son's deformed ankle as well as some temporary relief from the obligation of caring for his sick wife. The father's expectations come along with the private and unshared fear of being an outsider in Lisbon - the imperial capital he had learned to idealize as a civilized city: "E, ainda que sempre se tivesse sentido um coimbrão honorário, temia sem confessar à mulher não ser admitido em Lisboa, bastando que abrisse a boca para dizer 'Rossio'” (23).

Set between roughly 1985 and 1992, the narrative offers several flashbacks that describe the father's life during the last decade of colonial rule in Angola, a period during which he was a nursing assistant working closely with a Portuguese obstetrician. His trajectory exposes the complex identity of the colonized, who assimilates and tries to imitate the cultural practice of the colonizer. It is the father's collaboration with the colonizer that makes him believe that he may be recognized as Portuguese in Lisbon, but this could not be further from the truth. As the narrator puts it, the father-whose name is Cartola — is "um portuguesão dispensado pelo império a que jurara obediência, protegido por um tal Barbosa da Cunha que apenas se dera a ver uma vez desde que tinham chegado em Lisboa” (42). The doctor's lack of interest in helping his former assistant becomes obvious as the narrative progresses, even if Cartola pretends not to notice.

Almost from the opening of the novel, the reader comprehends that Lisbon will not be Cartola's imagined "cidade do progresso" (24), nor will it be a welcoming home. The metaphor of war-established as early as chapter threesets the tone for the gloomy reception that father and son will receive. Cartola arrives in Lisbon, for example, as a "soldado ferido de volta a casa" (24). In the words of the narrator, when Cartola says good-bye to his wife, "foi como se partisse para a guerra" (31), and there is even mention of him as "o herói de uma guerra sem sentido” (70). This bellicose imagery will find itself reinforced immediately by the first impressions that Cartola and his son have of Lisbon. Worth noting is the fact that Cartola and his son Aquiles consistently see Lisbon through windows (taxi, hostel), a symbol of confinement. On their first day in 
the city, Lisbon appears unwelcoming and cold: "Dentro de um táxi, com o olhar curioso de duas crianças, viram Lisboa pela primeira vez. Pareceu-lhes pequena e escura. [...] Caía uma chuva miudinha. Aquiles colou o nariz à janela do banco de trás e um coração feito com o dedo apareceu no vidro embaciado” (33).

The dystopian view of Lisbon only increases in intensity as the story progresses. One also notices Cartola's vulnerability and physical alteration since his departure from Luanda. Young Aquiles, just 15 years old, realizes that suddenly his father has aged: he looks smaller than before, and, for the first time, he seems disoriented. The first walk that father and son take through downtown Lisbon shows them a confusing and unknown city very different from the one Cartola had imagined. The unforeseen rainstorm serves as a kind of a baptism into an unexpected reality. Cartola feels lost, and Aquiles becomes fully aware of his loneliness. The narrator explicitly conveys their unfulfilled expectations:

Numa flânerie acabrunhada, deslumbravam-se com a falta de cheiro das ruas. Cartola parecia mais baixo ao filho desde que haviam chegado a Lisboa. A sua camisa fora engomada pela última vez ainda em Luanda. O filho olhava-o como quem teme que o rei sucumba a uma conspiração. A nobreza que o porte dele lhe inspirava em Luanda dera lugar à confusão de Cartola, que lhe fazia abrir muito os olhos como se tivesse medo de ir contra as coisas. [...]

Mas no interior de Cartola o mapa era ainda o mesmo. Caminhava sem referências. A nova cidade descarnada, sem arruamentos definidos, entontecia-o. Sentia as pernas tremer, perdia o equilíbrio, mesmo que soubesse não estar perdido. Sabia ir do Campo Grande aos Restauradores, traçado que imaginara anos a fio como uma marcha triunfal. Aterrado em Lisboa, porém, a cidade não era como tinha projetado. Nada ficava perto de nada nem era tão imponente como nos postais ilustrados do passado. [...]

Aquiles olhou para Cartola e reparou que o colarinho do pai pingava. A chuva não tem vontade própria, mas, ao cair, Aquiles sentiu que a água os lavava. À medida que se encharcavam e lhe começava a ser difícil arrastar o calcanhar, achou-se sem nada. 
Como poderia um rapaz sentir que perdera tudo se ainda não tinha uma história? A chuva dava-lhes as boas-vindas a Lisboa e, ao mesmo tempo, despia-os. [...]

Fora um aguaceiro, mas tinha chegado para revelar que a cidade era uma incógnita. Do cimo da Rotunda, Lisboa era perigosa. (37-39)

Infused with a strong sense of displacement, father and son are forced to construct and negotiate a new identity. Cartola understands that he will never be recognized as Portuguese, either socially or legally, despite the fact that he served the colonial administration and knows a great deal about Portugal and Portuguese culture. He also soon realizes that his supposed friend, Dr. Barbosa da Cunha, will not help him to navigate the Portuguese bureaucracy and obtain legal status for himself and his son. The mismatch between hope and reality is inscribed in a long list of rhetorical questions left unanswered (89). Aquiles also begins to see his father as "reticente e sombrio" (52). Sometimes Cartola resembles a lost child, and at others a disoriented old man. The city and its inhabitants, for their part, are both totally indifferent. Cartola moves through the city, "caminhando como se estivesse atarefado mas sem pressa para chegar a lado algum, apenas outro metido na sua vida, estava em sintonia com o ritmo da cidade, que o arrastava como uma maré. [...] Não era Cartola que fazia por não ser visto, mas a cegueira o que era a condição da cidade” (68).

Almeida captures the invisibility and the abandonment that characterize Cartola's experience in Portugal through a poignant metaphor-“era apenas um par de sapatos" (69) — and by a highly suggestive image of hunger: "tinha o estômago colado às costas" (69). Moreover, if Lisbon at first seems "silent" to Cartola and Aquiles, they soon realize that the city is not waiting for them, and neither is Dr. Barbosa da Cunha. At this point, Lisbon becomes a "barulheira" (67) and an "escadaria que não ia dar a parte alguma” (74). As for Aquiles, the broken promise of having his ankle fixed and his unconscious decision not to return to Angola forces him to negotiate a new identity. He stops feeling Angolan.

The impact of the hostile urban environment and the numerous difficulties these migrants face finds clear expression in the following excerpt, in which the narrator deconstructs a trope commonly used to describe the city and to highlight 
its attractiveness - the exceptionally beautiful light of Lisbon. By focusing on this trope, the narrator emphasizes the socio-economic exclusion that confines Cartola and Aquiles to Paraíso, a slum on the outskirts of Lisbon, where poor housing conditions abound. This has a dramatic effect on Aquiles, who struggles to thrive in a “cidade sem árvores” (78):

[Aquiles] chegou a acreditar que podia ser quem quisesse. Mas o dinheiro não chegava, e nem sequer sabia por onde começar. Não tinha amigos e não se abria com o pai. [...] Luanda tornarase para ele uma miragem e Lisboa era uma cidade sem árvores. [...] A sua adolescência foi uma brisa que percorreu Lisboa ao fim da tarde e agitou apenas uma folha. Quando deu por si, era um homem e tinha o pai às costas. Fala-se da luz de Lisboa, mas ela não iluminou Aquiles. Penou, sonhou e, num dia como outro qualquer, secou antes de dar flor. (78)

Seven years after their arrival in Lisbon, father and son are undocumented migrants working illegally in construction, which barely allows them to pay for their food. Aquiles remains disabled, and, when Cartola's daughter comes from Luanda to visit them, Lisbon is as uninviting as ever. Her father and brother seem like strangers to Justina, and Paraíso is far from a promising destination. The view from the car window foreshadows Justina's disillusionment:

Como Aquiles e Cartola quando desembarcaram em Lisboa, a mulher viu a cidade pela janela e teve direito a uma volta pela Baixa antes de rumarem a Paraíso. Fontes, estátuas, passeios, pareceram-lhe gastos, velhos, sem interesse, sujos. Estava uma manhã de luz branca. Ela olhava pelo vidro como a caminho de ver desvendado um segredo. [...]

Cartola já não era bem o mesmo nem ela a mesma filha que ele tinha deixado em Luanda. Se ela vinha para cuidar dele e do irmão por um Verão, não sabia bem que dois homens tinha a seu cargo. [...] Nada disse perante a visão do pátio e das barracas quando chegaram. Nem sequer lamentou a fachada triste do casebre. (125-26) 
At the time of Justina's visit, father and son still have not unpacked their suitcases, which signals their exclusion from Lisbon's cityscape, and thus from Portuguese society. The two men are living with the temporary mindset of those who still hope to reach a better place. Their dislocation from the city center to the periphery reveals a process of accelerated social exclusion. At one point, the narrator highlights Cartola and Aquiles's inertia, as if an invisible chain of uncontrolled forces had pushed them toward the margins, erasing their memories of Angola and rendering them incapable of expressing emotion:

A história empurrou-os para uma margem sem que dessem conta de que tinham chegado a terra. [...]

Aquiles e o pai estavam protegidos pela bruma que era a sua existência sem documentos. E então podiam dormir descansados sem serem picados pela agulha de quem quisesse roubar-lhes a palavra, indiferentes às suas dores e às variações da sua ambivalência, sem entender por que se tinham tornado incapazes de chorar, por que tinha a memória da sua terra desaparecido do seu coração, por que não se decidiam a regressar e por que não se queixavam. (173)

Having arrived in Portugal through an international agreement, the two men soon understand that they will receive very little support. Furthermore, the absence of a support system rapidly transforms them into regular migrants pushed to the margins of society, condemning them to an "existência sem documentos” (173).

Agostinho Rodrigues Silvestre and Luís Fernandes describe the vicious cycle that reinforces social marginalization:

Numa situação de 'penúria' de emprego e de recuo do estado social, o facto de se viver num 'bairro social degradado' pode condicionar, ainda mais negativamente, o percurso profissional dos que lá habitam. Viver nesses territórios significa estar, frequentemente, em situação de múltipla relegação. A relegação dessas populações não é, com efeito, apenas por parte dos 
empregadores, mas também da polícia, dos tribunais, dos serviços de apoio social [...] e dos próprios vizinhos. (40)

If D'Santiago works in "Nova Lisboa" to create a space that transcends the center-periphery dichotomy, Almeida's concept of periphery is undoubtedly negative, and it is probably related to the fast and chaotic growth of the Lisbon suburbs during the 1980s and 1990s. The cultural resistance and creativity that have flourished on the outskirts of the Portuguese capital over the last two decades (a movement linked to the idea of multi/reterritorialization) are central to any adequate understanding of "Nova Lisboa," but this is not to be found in Almeida's novel. ${ }^{2}$ In Luanda, Lisboa, Paraíso, the periphery is synonymous with exclusion and marginalization. Cartola and Aquiles in fact have very little, if any agency at all. Their trajectory in Lisbon consists of a chain of losses, a complete defeat. After Justina's return to Luanda, father and son grow even further apart. Cartola continues to be stuck in the past and lives in an imaginary Lisbon, still waiting (or pretending to wait) for some sort of help from Dr. Barbosa da Cunha. Aquiles, feeling completely uprooted, lives in a state of deep solitude. His nightly walks through Lisbon—intended as a break from the misery of Paraíso-reflect, reveal, and worsen his loneliness. In these moments of the narrative, suggestive metaphors depict the total absence of enchantment and hope that characterizes Lisbon. Aquiles is described as a "cão manco" working his way through a formless and "irrespirável” city (168). In this dreadful scenario, Aquiles is but a "marinheiro em terra, um pescador sem história, o nativo perfumado, o operário coxo" (169). The hopelessness comes to a sort of climax on the following page, as the narrator turns directly to Aquiles: "Meu bom Aquiles, quão longe estás tu de casa? Já não há outra casa para além dos toldos da Rua Augusta, do cheiro a mijo das casas de banho do Terminal do Rossio, das Escadinhas do Duque, que sobe aos tombos, escadinhas de Sísifo” (170). In sum, the indifference of Lisbon comes to reflect and exacerbate Aquiles's loneliness and despair.

Cartola and Aquiles's involuntary destination-ironically named "Paraíso"—-does not bring significant material change to their lives, except for

\footnotetext{
${ }^{2}$ For more on reterritorialization and multiterritoriality, see Haesbaert. On the contemporary debate over the periphery as a welcoming, creative, nonconforming, heterogeneous, transnational and political space of cultural resistance and disobedience, see Martins and Canevacci; and Loria.
} 
the camaraderie and solidarity that Cartola finds in his friendship with Pepe, a Galician who arrived in Portugal as a child. This suburban area is unsurprisingly almost always described in relation to Lisbon, and all references to Paraíso reinforce the irony and the tragedy behind the name. Paraíso is located "num vale do qual apenas se erguiam do chão cascalho, ervas daninhas e postes de alta tensão" (99), and it is a "lugarejo demasiado distante para ser visitado por tementes, arrabalde que nenhum apóstolo conseguiria resgatar do fim do mundo, com o seu álamo esquecido e a ladainha do seu autocarro a caminho da cidade onde tudo, visto dali, era a giz e sem contorno e a gente era sem nariz nem queixo" (174). Throughout the novel, Lisbon is a place of hope that leads only to complete disaffection. No description of Lisbon and, later, Paraíso is positive, and at no point does the city environment help Cartola and Aquiles to thrive.

Besides exposing the negative reception that Lisbon offers Cartola and Aquiles, Almeida's novel also calls attention to instances of internalized and systemic racism. For instance, when Aquiles, his sister, and her daughter have a small picnic by the Praça de Espanha, they draw reactions from people in the cars passing by:

Os carros abrandavam no semáforo e alguns reparavam no piquenique das três estátuas negras sentadas. Restaurados com a merenda, eles riam-se da cara dos distraídos que tiravam macacos do nariz ou pintavam os lábios à pressa no espelho sabendo que dentro de instantes o semáforo abriria e não lhes pediam conta das gargalhadas. Mas não se saberia dizer quem observava, pois os outros, ao passarem de raspão, também os viam e eram aos olhos deles três pobres diabos sem destino, uma família de chimpanzés vestidos de gente. (144)

The trio seems out of place to those who pass by them, and there is a notable brutality to the language Almeida employs.

Commenting on João Botelho’s 1985 film, Um adeus português, Carolin Overhoff Ferreira calls attention to a key scene in which an African character interrupts a woman singing fado. For Ferreira, this scene suggests that for many Portuguese, the presence in Portugal of African immigrants (or even Afro- 
Portuguese) is "potentially threatening to Portuguese identity" (74). She goes on to add that "the Other remains a problem for Portugal's post-colonial identity" (74). Ferreira's argument is also applicable to the Praça de Espanha scene in Luanda, Lisboa, Paraíso. The family picnic near the street and the reaction of passersby also reveals how "race appears to have been more a silenced subject than an actual point of discussion in Portugal” (Medeiros, "Postimperial” 252).

\section{Final Remarks}

Contrary to Lisbon Tales and Trails, Almeida's novel sheds light on the experience of a community that lacks representation but has been highly visible in the Lisbon cityscape for at least the last five decades-the African diaspora. In doing so, Almeida offers a new perspective on the city that goes beyond the touristic postcard version of Lisbon. Furthermore, the representation of Lisbon in this novel helps to expose complexities deeply connected to the legacies of the empire. Cartola has assimilated the culture of the colonizer; however, he has no advantage with regard to his legal status in Portugal. As for Aquiles, he is in a much more unfortunate situation, due to his physical limitations and his feeling of displacement, a state very common among migrants. Given that these two characters are denied any semblance of dignity or recognition, it is worth pointing out the tragic irony behind their names: cartola is a common term for "top hat," a formal hat used by individuals of high social standing, and Aquiles (Eng. "Achilles”) is of course the name of a nearly invulnerable Homeric hero.

In my reading, Almeida's novel not only complements the perceptions of the capital included in Lisbon Tales and Trails but also challenges them. In "A note from the Editors”, one reads, "a city owes its richness and significance to its citizens, true artists, for they sow the seeds that enable a city to become more than a sum of its parts” (7). What Almeida seems to underline with her novel, however, is that a city gains significance from all who inhabit it, citizens or not. It is clear that Cartola feels a deep love for Lisbon, but he gets nothing positive in return. In fact, as the narrator tragically concludes: "De Portugal, a cidadania dos mortos foi o seu único visto de residência” (223). According to Margarida Calafate Ribeiro, "resta-lhe uma cidadania espetral de um mundo de fantasia que a história transformou em fantasma. Lisboa não existe” (8). The final image of 
Cartola throwing his top hat into the Tagus River rightfully expresses his abandonment of the desire to belong to Portuguese society.

Both Epalanga's short story and Almeida's novel address the complexities and ambiguities that inhabit Lisbon and its broader metropolitan areacharacteristics that are deeply connected with the legacies of the empire. The narrators and characters created by these writers inhabit a Lisbon "still waiting for the postcolony to arrive in this ongoing, permanent process of decolonization" (Coelho 200). Walking through the main arteries of the capital or traveling from the city center to the suburbs, the readers of these texts have access to a complex view of the Portuguese capital's postcolonial ethnoscape, and they encounter un(der)represented characters that have been historically marginalized. Additionally, by focusing on Portuguese society in light of its imperial past, these two writers contribute to the current reflection on Afropolitan (Selasi) or Afropean (Pitts) experiences in contemporary Europe. They provide, as Medeiros would say, "some grounds for cultural resistance" ("Exit Ghost" 249). In constructing powerful fictional narratives with no easy solutions to a multi-dimensional problem-one that touches on politics, economics, class, and race-Almeida and Epalanga make significant and original contributions to the debate on racism, identity politics, belonging, and social integration in contemporary Portuguese society.

\section{Works Cited}

Almeida, Djaimilia Pereira de. Luanda, Lisboa, Paraíso. Companhia das Letras, 2018.

Appadurai, Arjun. "Global Ethnoscapes: Notes and Queries for a Transnational Anthropology." Interventions: Anthropologies of the Present. School of American Research, edited by Richard G. Fox, School of American Research P, 1991, pp. 191-210.

Arena, Joaquim. Debaixo da nossa pele: uma viagem. Imprensa Nacional-Casa da Moeda, 2017.

Arenas, Fernando. "Migrations and the Rise of African Lisbon: Time-Space of Portuguese (Post)coloniality.” Postcolonial Studies, vol. 18, no. 4, 2015, pp. 353-66. 
Botelho, João, director. Um adeus português. Electric Pictures/Contemporary Films Ltd., 1985.

Calvino, Italo. As cidades invisíveis. Translated by Diogo Mainardi, Companhia das Letras, 1990.

Coelho, Rui Gomes. “An Archaeology of Decolonization: Imperial Intimacies in Contemporary Lisbon.” Journal of Social Archaeology, vol. 19, no. 2, 2019, pp. 181-205.

Conexão Lusófona. 2006, conexaolusofona.org/.

D’Santiago, Dino. “Nova Lsboa.” YouTube, 23 Nov. 2018, youtube.com/watch?v= ZwgO8AbkoPE.

Ferreira, Carolin Overhoff. Identity and Difference: Postcoloniality and Transnationality in Lusophone Films. LIT Verlag, 2012.

Haesbaert, Rogério. O mito da desterritorialização: do "fim dos territories" à multi-territorialidade. Bertrand Brasil, 2004.

Lisbon Tales and Trails. Empresa de Gestão de Equipamentos e Animação Cultural, 2017.

Loria, Luana. Manifestações artísticas como contra-narrativas: estudos de casos das periferias. U Federal de Santa Catarina, 2017.

"Lusofonia, a (r)evolução.” YouTube, uploaded by produxoesxl, 29 Jul. 2011, youtube.com/watch?v=JaBjo0TQTfk.

Malheiros, Jorge, and Francisco Vala. "Immigration and City Change: The Lisbon Metropolis at the Turn of the Twentieth Century." Journal of Ethnic and Migration Studies, vol. 30, no. 6, 2004, pp. 1065-86.

Martins, Rosana, and Massimo Canevacci, editors. Lusophone Hip-Hop: 'Who We Are' and 'Where We Are': Identity, Urban Culture and Belonging. Sean Kingston, 2013.

Medeiros, Paulo de. "Exit Ghost: Reading Lusotropicalism as Fetish (with Adorno).” Portuguese Studies Review, vol. 26, no. 1, 2018, pp. 247-71.

- . "Postimperial Lisbon." Cities of the Lusophone World Literature, Culture and Urban Transformations: Reconfiguring Identities in the PortugueseSpeaking World, edited by Doris Wieser and Ana Filipa Prata, Peter Lang, 2018, pp. 195-216.

Neves, Branca Clara das. Luena, Luanda, Lisboa: Fala de Maria Benta. Colibri, 2014. 
Peralta, Elsa, and Nuno Domingos. "Lisbon: Reading the (Post-)colonial City from the Nineteenth to the Twenty-First Century.” Urban History, vol. 46, no. 2, 2019, pp. 246-65.

Pitts, Johny. Afropean: Notes from Black Europe. Allen Lane, 2019.

Ribeiro, Margarida Calafate. "Sentimentos de outros ocidentais." Memoirs, edited by António Pinto Ribeiro, 27 Sept. 2019, pp. 1-23.

Selasi, Taiye. "Bye-Bye Babar (Or: What is an Afropolitan?).” The Lip, 3 Mar. 2005, thelip.robertsharp.co.uk/?p=76.

Silvestre, Agostinho Rodrigues, and Luís Fernandes. "Trabalho e processos de marginalização social no século XXI.” Sociologia, vol. 27, 2014, pp. 27-44. Stoler, Ann Laura. Imperial Debris: On Ruins and Ruination. Duke UP, 2013. 